International Research Journal of Management, IT \& Social Sciences
Available online at https://sloap.org/journals/index.php/irjmis/
Vol. 6 No. 4, July 2019, pages: 189 196
ISSN: 2395-7492
https://doi.org/10.21744/irjmis.v6n4.680

\title{
Halo Effect Moderating: Impact of Professional Skepticism on Auditor Performance
}

\author{
Ihwan Septian ${ }^{\text {a }}$ \\ Ida Bagus Putra Astika ${ }^{\text {b }}$
}

Article history:

Received: 18 March 2019

Accepted: 31 May 2019

Published: 30 July 2019

\section{Keywords:}

auditor; halo effect; performance; professional; skepticism;

\begin{abstract}
The Public Accountant profession has a role in supporting a healthy and efficient economy and increasing transparency and quality of financial information. Good auditor performance is needed to provide transparent and quality financial information to all interested parties. Good auditor performance can be carried out if an auditor is able to maintain professional skepticism and other factors in carrying out audit assignments and is not affected by factors that can reduce professional skepticism, one of which is the occurrence of a halo effect in assessing the client's overall business risk. The research was conducted to provide empirical of the halo effect in moderating professional skepticism on the auditor performance at Public Accounting Firm $(K A P)$ in Bali Province. The population in this research were all KAP auditors in Bali Province which registered in the Directory and published by Indonesian Institute of Certified Public Accountants (IAPI) in 2019. The sampling technique used purposive sampling with the auditor criteria who are actively working in KAP in Bali Province and has audit experience of at least one year and ever been a team leader in the audit at least once.
\end{abstract}

2395-7492@ Copyright 2019. The Author. This is an open-access article under the CC BY-SA license (https://creativecommons.org/licenses/by-sa/4.0/) All rights reserved.

Author correspondence:

Ihwan Septian,

Faculty of Economics and Business,

Udayana University, Bali, Indonesia.

Email address: ihwan.septian@gmail.com

\section{Introduction}

Auditors as a profession of public trust have begun to question their performance in terms of examining and evaluating company reports. This is because there are auditors who fail to evaluate the evidence because the objectivity principle is not applied, the lack of understanding of existing audit procedures and auditors tend to trust the client so that it will lead to bias in conducting an assessment resulting in a decrease in audit quality produced. The auditor's profession has high responsibility. Good performance is needed because the auditor profession has an important role

\footnotetext{
a Faculty of Economics and Business, Udayana University, Denpasar, Indonesia ${ }^{\mathrm{b}}$ Faculty of Economics and Business, Udayana University, Denpasar, Indonesia
} 
in providing reliable financial information to the government, investors, creditors, debtors, shareholders, employees and the public and other interested parties.

Falikhatun (2003), states that the increase in performance in his work is influenced by certain conditions, namely conditions originating from within an individual called individual factors and conditions that originate outside the individual called situational factors. Professional auditor skepticism is the attitude of the auditor who always doubts and questions everything, and critically assesses audit evidence and takes audit decisions based on his auditing expertise. Professional skepticism is one of the factors that arise in the internal individuals that influence the improvement of auditor performance Auditor professional skepticism is an attitude or mindset of auditors who are always vigilant and question the correctness of audit evidence presented by a business entity or company (Purwanti \& Astika, 2017; Aditya \& Kusuma, 2019).

A skeptical auditor, will not take for granted an explanation from the client but will ask questions to obtain reasons, evidence and confirmation regarding the object in question. Nila (2014), states that an auditor's performance is good for the fairness of a financial report, can be carried out through skepticism to be able to decide or determine the extent of the accuracy and truth of the evidence. Professional skepticism will assist the auditor in critically assessing the risks faced and taking into account these risks in various decisions to accept or reject clients, choose appropriate audit methods and techniques, and assess audit evidence collected. Without applying professional skepticism, the auditor will only find misstatements caused by mistakes and it is difficult to find misstatements caused by fraud because fraud will usually be hidden by the perpetrators (Noviyanti, 2008). The auditor is required to carry out his professional skepticism so that the auditor can use his professional skills carefully and thoroughly because the professional skills of an auditor influence the results of the work he gives (Luz, 2012).

Previous research on professional skepticism on auditor performance has been carried out by Priesty \& Budiartha (2017), giving results that professional skepticism has a positive effect on auditor performance in public accounting firms in Bali. Professional skepticism, in this case, provides more audit information results and strongly supports the performance of an auditor. Sari et al., (2016) and Rahmawati et al., (2019), also revealed that professional skepticism has a positive effect on auditor performance. Auditors who are skeptical will not rush to make a decision before the information can be valid and always carry out critical evaluations. However, this is not in line with the research of Peytcheva (2013), which states that skepticism does not have an additional effect on auditor performance.

Murray (1990), explains that in order to reconcile conflicting results a contingency approach is needed to identify other variables that act as mediating variables or moderating variables. In this study using the Halo Effect variable as a moderating variable because this variable is thought to have an effect on the relationship of professional skepticism to auditor performance. Koroy (2005), explains the halo effect can affect the auditor's professional skepticism by influencing the way he deals with client preferences and ambiguous and disconfirming information. Halo Effect is defined as the effect of a global evaluation based on one's individual attributes, this applies especially if a person does not have enough information about all of a person's characteristics (Thorndike, 1920; Dewi et al., 2018; Negara \& Budiartha, 2019).

Halo Effect causes auditor perceptions to vary and leads to confidence in certain audit conditions. Halo Effect usually occurs during the first meeting and occurs due to the way of thinking of individuals who tend to make categorizations regarding human nature, namely categories of good and bad traits. Viewed from this perspective the halo effect error can be considered as a special subcategory of hasty generalizations, or generalizations of insufficient evidence (Thorndike, 1920 and Grcic, 2008).

The Nisbet \& Wilson (1997) study in Arel et al., (2005), states that the phenomenon of halo effects occurs in various work evaluation contexts. These findings provide evidence that auditor judgment can be biased by the existence of a halo effect. Utami et al., (2014), the study also strengthened the research of Arel et al., (2005), which found that the halo effect phenomena occur between auditors. This is contrary to the expectations of Gramling et al., (2010), the findings do not provide evidence that knowledge of inherent risk factors creates halo effects that can affect the auditor's judgment. Auditing judgment accuracy is one indicator that can be used to measure auditor performance.

Koroy (2005), also stated the need for behavioral research in auditing to increase knowledge in improving auditor performance. In this case, the evidence leads to the fact that auditors in the public accounting environment are subjects that can be influenced and have the potential to compromise their professional decisions (Rahmawati \& Honggowati, 2004).

Research on auditor performance is still very necessary because the auditor's function (testing) has a problem or conflict that arises, one of which is the existence of disagreement between the auditor and the client will influence the audit process so the client can press the auditor to take actions that violate the inspection standards. Based on the 
background above, this study takes the title of Halo Effect as Moderating the Effects of Auditor Professional Skepticism on Auditor Performance at the Bali Regional Public Accountant Office.

\section{Literature Review and Hypothesis Development}

\section{The Effect of Professional Skepticism on Auditor Performance}

Specifically in auditing, in the Professional Standards of Public Accountants, it is explained that professional skepticism is an attitude that includes a mind that is always questioning, alert to conditions that may indicate the possibility of misstatements either caused by fraud or errors, and an important assessment of audit evidence (IAPI, 2011). An auditor's professional skepticism is needed in assessing and critically taking into account the risks faced to accept or reject clients, choose appropriate audit methods and techniques, assess audit evidence collected. Skeptical auditors will not take the explanation from the client for granted but will ask questions to obtain reasons, evidence, and confirmation regarding the object in question and always be aware of contradictory audit evidence so that the resulting judgment will be optimal (Rusyanti, 2010). Without applying professional skepticism, the auditor will only find misstatements caused by mistakes and it is difficult to find misstatements caused by fraud because fraud will usually be hidden by the perpetrators (Noviyanti, 2008). Research conducted by Rahmawati et al., (2019), found that an auditor who has professional skepticism is able to provide maximum and objective financial statements. The effect of professional skepticism on auditor performance in terms of providing more and more significant results of audit information than auditors who have a low level of professional skepticism, and this results in auditors having high professional skepticism. Will be better able to detect fraud because of the information they have. Priesty \& Budiartha (2017) and Sari et al., (2016), also provides results that professional skepticism has a positive effect on auditor performance in public accounting firms in Bali. Professional skepticism, in this case, provides more audit information results and strongly supports the performance of an auditor.

H1: Professional skepticism has a positive effect on Auditor Performance.

\section{Halo Effect Moderates the relationship between Professional Skepticism on Auditor Performance}

Thorndike (1920), defines a halo effect as the effect of a global evaluation based on one's individual attributes, this applies especially if someone does not have enough information about all of a person's characteristics. In auditing, a halo effect arises from the overall assessment of a client's business risk and can be biased with the auditor's performance related to potential misstatement as evidenced by detailed information on the pattern of account balance fluctuations (O’Donnell \& Schultz, 2005). Research by Octavian \& Intiyas (2016), explains that the effect of a high halo effect will result in audit decisions with a low level of accuracy. The research of Arel et al., (2005), explains that the halo effect will make auditors tend to believe in their initial assessment so that it will produce inappropriate audit decisions. Halo Effect causes the auditor to easily trust the information obtained and will ignore facts that have not been revealed about the client during the audit process. Auditors with a high level of trust in clients will cause professional skepticism to decline so that it will affect the decline in the quality of audit performance. Based on the description above, the formulated hypotheses are as follows:

H2: Halo Effect can weaken the influence of professional skepticism on auditor performance.

\section{Materials and Methods}

This research was conducted at the Public Accounting Firm (KAP) in Bali Province which is listed in the Directory published by the Indonesian Institute of Certified Public Accountants (IAPI) in 2019. The population in this study were all auditors at the Public Accounting Firm in Bali Province registered in the published Directory. by the Indonesian Institute of Certified Public Accountants (IAPI) in 2018. The sampling technique used in this study was purposive sampling, with the criteria of auditors who were sampled having a minimum tenure of years of work or audit experience ever been a team leader in the audit at least once. The data analysis model and hypothesis testing in this study are simple linear regression analysis models, multiple linear regression analysis models and moderated regression analysis.

Septian, I., \& Astika, I. B. P. (2019). Halo effect moderating: impact of professional skepticism on auditor performance. International Research Journal of Management, IT and Social Sciences, 6(4), 189-196. 


\section{Results and Discussions}

The results of the linear regression analysis models are presented in Table 1.

Tabel 1

Linear Regression Analysis

\begin{tabular}{|c|c|c|c|c|c|c|}
\hline \multirow[t]{2}{*}{ Variable } & \multicolumn{2}{|c|}{$\begin{array}{l}\text { Unstandardized } \\
\text { Coefficient }\end{array}$} & \multirow{2}{*}{$\begin{array}{l}\text { Standardized } \\
\text { Coefficient } \\
\text { Beta }\end{array}$} & \multirow[t]{2}{*}{$\mathrm{T}$} & \multirow[t]{2}{*}{ Sig. } & \multirow[t]{2}{*}{ Keterangan } \\
\hline & B & Std. Error & & & & \\
\hline Constant & 3,630 & 2,478 & & 1,465 & 0,149 & \\
\hline $\begin{array}{l}\text { Professional } \\
\text { Skepticism }\end{array}$ & 0,458 & 0,054 & 0,752 & 8,468 & 0,000 & $\mathrm{H}_{1}$ accepted \\
\hline $\begin{array}{l}\text { R Square }=0,566 \\
F \text { count }=71,703 \\
\text { Sig. } F=0,000\end{array}$ & & & & & & \\
\hline
\end{tabular}

The results of the multiple regression analysis models are presented in Table 2.

Tabel 2

Multiple Regression Analysis

\begin{tabular}{llllll}
\hline \multirow{2}{*}{ Variable } & \multicolumn{2}{c}{ Unstandardized Coefficient } & $\begin{array}{c}\text { Standardized } \\
\text { Coefficient }\end{array}$ & T & \multirow{2}{*}{ Sig. } \\
\cline { 2 - 4 } & $\mathrm{B}$ & Std. Error & Beta & & \\
\hline Constant & 34,793 & 8,696 & & 4,001 & 0,000 \\
Professional Skepticism & 0,091 & 0,110 & 0,150 & 0,827 & 0,412 \\
Halo Effect & $-3,937$ & 1,062 & $-0,672$ & $-3,708$ & 0,000
\end{tabular}

R Square $=0,654$

$\mathrm{F}$ count $=51,034$

Sig. $F=0,000$

Primary Data, 2019

The results of the moderated regression analysis models are presented in Table 3 .

Tabel 3

Moderated Regression Analysis

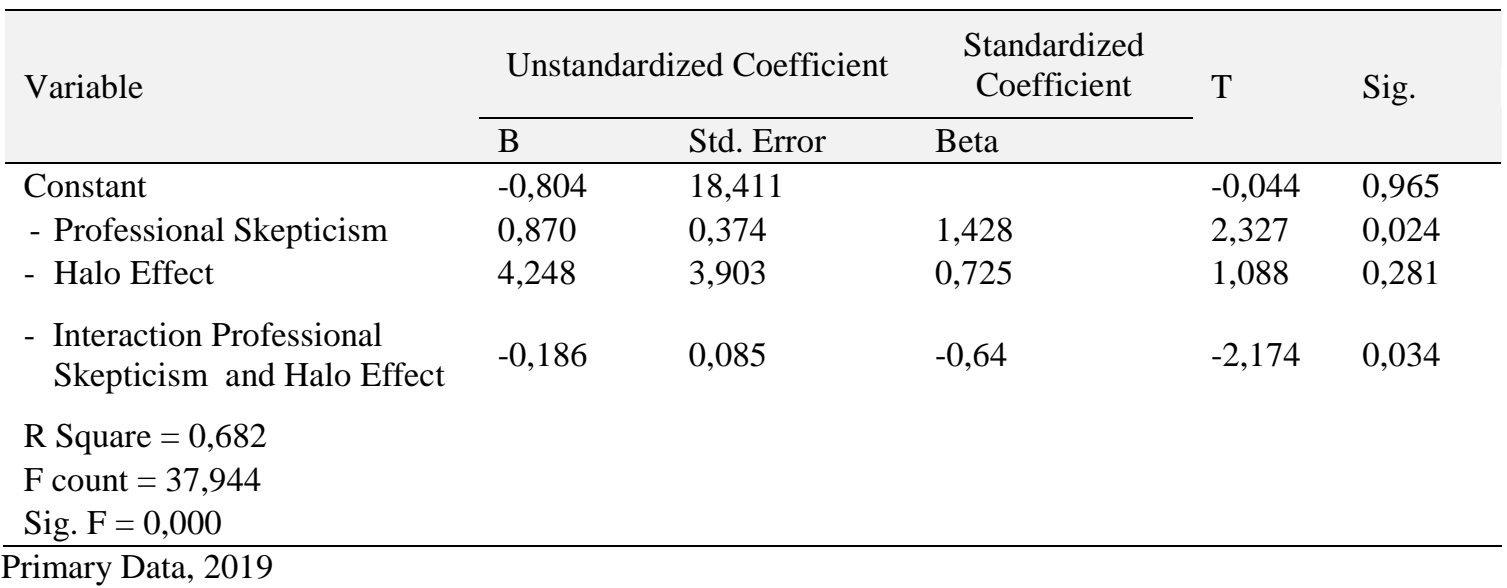


Determination Coefficient

Based on Table 1 the Adjusted R-square value of 0,566 shows that the changes that occur in auditor performance can be explained by professional skepticism of 56,6 percent, the remaining 43,4 percent is influenced by other variables not included in this research model.

Based on Table 2 the Adjusted R-square value of 0,654 shows that the changes that occur in auditor performance can be explained by professional skepticism of 65,4 percent, the remaining 34,6 percent is influenced by other variables not included in this research model.

Based on Table 3 the Adjusted R-square value of 0,682 shows that the changes that occur in auditor performance can be explained by professional skepticism of 68,2 percent, the remaining 31,8 percent is influenced by other variables not included in this research model.

\section{The Result of Hypothesis}

\section{The Effect of Professional Skepticism on Auditor Performance}

The first hypothesis of this study states that professional skepticism has a positive effect on auditor performance. The test results of the professional skepticism variable using simple linear regression show a positive regression coefficient of 0.481 . The level of significance indicates a value of 0,000 which is smaller than the acceptable error rate of $5 \%(0,000<0,05)$. Positive regression coefficient values indicate a unidirectional relationship between professional skepticism and auditor performance. The higher the professional skepticism of the auditor, the higher the performance will be.

Professional skepticism is the attitude of the auditor who always doubts and questions everything and critically assesses audit evidence and takes audit decisions based on his auditing expertise. Auditors who have a high attitude of professional skepticism will not be easily affected by the information provided. However, auditors who have a low attitude of professional skepticism, will trust the information conveyed by management and influence the decline in auditor performance as explained in cognitive theory that personal character has a direct relationship to individual decision making and attribution theory that other aspects of individual behavior exist in a person, external causes can also influence a person's attitude or behavior in this study is professional skepticism. The results of this study support the research conducted by Rahmawati et al., (2019); Priesty \& Budiartha (2017); and Sari et al., (2016), which states that auditor professional skepticism has a positive effect on auditor performance.

\section{Halo Effect Moderate the Effects of Professional Skepticism on Auditor Performance}

According to Ghozali (2016), the determination of the moderator variable is based on its relationship with the criterion variable (independent) and its interaction with the predictor variable (dependent). Based on the results of the analysis in Table 2, it shows that the halo effect has a negative regression coefficient of 3.937 with a significance level of 0.000 which is smaller than the acceptable error rate of $<0.05$. This shows that there is a relationship between the halo effect and auditor performance. The relationship between the interaction between professional skepticism and the halo effect on auditor performance can be seen in Table 3 which shows that the regression coefficient of interaction between professional skepticism and negative halo effect is 0.186 with a significance level of 0.034 which is smaller than the acceptable error rate $<0.05$. This shows that the halo effect interacts with professional skepticism. Based on these results, it can be concluded that the halo effect is a quasi moderation variable (quasi moderator).

According to Utama (2016), if the moderating variable interacts with the independent variable and correlates significantly with the dependent variable, then the moderation variable strengthens or weakens the influence of the independent variable on the dependent variable, namely by observing the regression coefficient $(\beta)$ independent variable interaction and moderation variable. Based on Table 3, the regression coefficient of professional skepticism $(\beta 1)$ is positive at 0.870 and the regression coefficient of professional skepticism interaction with negative halo effect ( $\beta 3$ ) is 0.186 with a significance level of 0.034 which is smaller than the acceptable error rate $<0.05$, then $\mathrm{H} 2$ is accepted. This means that the halo effect weakens the influence of professional skepticism on auditor performance. The results of this study support the attribution theory, a theory that explains that there are behaviors that are related to individual attitudes and characteristics. This theory explains that only by looking at his behavior will be able to know the attitude or characteristics of the person. The auditor's performance can be seen in his personal characteristics. Personal characteristic is an internal factor that encourages a person to carry out activities. The personal characteristics

Septian, I., \& Astika, I. B. P. (2019). Halo effect moderating: impact of professional skepticism on auditor performance. International Research Journal of Management, IT and Social Sciences, 6(4), 189-196. 
of the auditor are seen from the attitude of professional skepticism and the ability to overcome the effects of the halo effect. The results of this study also support the theory of aspects of psychological bias. This theory has a role in shaping individual behavior in decision making. Korroy (2005), explains that different people will reach different conclusions in understanding the same information. Psychological bias distorts how people interpret information. Psychological bias causes people to tend to choose the information that leads to their perceptions, regardless of whether the information is right or wrong because they prefer information that fits their beliefs.

Halo Effect usually occurs during the first meeting with the client. At that time an auditor can make varied assessments so that his assessment of the client can be biased and subjective. Thoughts can cause the auditor to ignore facts about the client being audited, or when interacting. Pramesthi (2013), explains that often accountants are subjective and there is a close relationship between KAP and its clients, even the most honest and careful auditors will inadvertently distort the numbers so that they can cover up the actual financial situation of a company. Auditors affected by the Halo Effect will ignore important information from clients which can be said that he did not apply his skepticism.

The effect of Halo Effect which lowers the auditor's skepticism will have an impact on the timing, nature, and extent of audit procedures. Halo Effect causes auditors to test unilaterally and look for evidence that is consistent with their hypotheses and choose to accept allegations rather than looking for all relevant evidence so that auditors are reluctant to look for other alternatives (Shefrin, 2007). This has an impact on the accuracy of the judgments produced by the auditor in completing his audit work to influence low-quality audit decisions. This research is in line with the research of Octavian \& Intiyas (2016), that the high influence of Halo Effect will produce audit decisions with a low level of accuracy. The research of Arel et al., (2005) and Santoso (2013), explains that Halo Effect will make auditors tend to believe in their initial assessment so that it will produce inappropriate audit decisions.

\section{Conclusion}

Based on the results of the analysis in this study, it can be concluded that professional skepticism has a positive effect on auditor performance and the halo effect weakens the effect of auditor professional skepticism on auditor performance. This shows that the higher the professional skepticism of an auditor will directly improve the auditor's performance, but if the halo effect occurs on the auditor, it will reduce the influence of professional skepticism in improving auditor performance.

Based on the results of the analysis and conclusions, the suggestions that can be given to auditors, public accounting firms and subsequent research are as follows: Auditors should adopt high professional skepticism in carrying out audit assignments to avoid the occurrence of halo effects and for public accounting firms, broadening the understanding of its staff in relation to the code of ethics of public accountants and encouraging professional skepticism through training or seminars related to professional skepticism. Future studies can conduct in-depth interviews with respondents related to research variables to obtain more information from respondents so as to maximize the extraction of data and information needed for research.

Conflict of interest statement and funding sources

The authors declared that they have no competing interest.

Statement of authorship

The authors have a responsibility for the conception and design of the study. The authors have approved the final article.

\section{Acknowledgments}

The authors would like to thank the Editor of IRJMIS for their valuable time, support, and advice in completing the current study. 


\section{References}

Aditya, A. G. D., \& Kusuma, M. G. W. (2019). The effect of tri hita karana culture in relationship between work stress and internal auditor performance. International Research Journal of Management, IT and Social Sciences, 6(2), 72-78. https://doi.org/10.21744/irjmis.v6n2.610

Arel, B., Kaplan, S. E., \& O'Donnell, E. (2006). Halo effects during internal control evaluation: The influence of management self-assessment on auditor judgment. In Proceeding of mid year meeting of the auditing section of the american accounting association (pp. 1-30).

Cabrera-Frias, L. (2012). The ethics of professional skepticism in public accounting: How the auditor-client relationship impacts objectivity (Doctoral dissertation, Georgetown University).

Dewi, I. G. A. A. P., \& Dewi, P. P. (2018). Big Five Personality, Ethical Sensitivity, and Performance of Auditors. International Research Journal of Management, IT and Social Sciences, 5(2), 195-209.

Dewi, P. P., \& Dwiyanti, K. T. (2018). Professional commitment, self-efficacy and ethical decision auditor. International Research Journal of Management, IT and Social Sciences, 5(6), 93-104. https://doi.org/10.21744/irjmis.v5n6.379

Falikhatun, F., \& Assegaf, Y. U. (2012). Bank Syariah Di Indonesia: Ketaatan Pada Prinsip-Prinsip Syariah Dan Kesehatan Finansial. In 1st Conference in Business, Accounting, and Management 2012. Sultan Agung Islamic University.

Ghozali, I. (2018). Aplikasi analisis multivariete dengan program IBM SPSS 23.

Gramling, A. A., O’Donnell, E., \& Vandervelde, S. D. (2010). Audit partner evaluation of compensating controls: A focus on design effectiveness and extent of auditor testing. Auditing: a journal of practice \& theory, 29(2), 175187.

Grcic, J. (2008). The halo effect fallacy. Electronic Journal for Philosophy, 15(1), 1-6.

Gustia, N. (2014). Pengaruh Independensi Auditor, Etika Profesi, Komitmen Organisasi, Dan Gaya Kepemimpinan Terhadap Kinerja Auditor Pemerintah (Studi Empiris pada Auditor Pemerintah di BPKP Perwakilan Sumbar). Jurnal Akuntansi, 2(3).

Koroy, T. R. (2007). Pengaruh Preferensi Klien dan Pengalaman Audit Terhadap Pertimbangan Auditor. The Indonesian Journal of Accounting Research, 10(1).

Murray, D. (1990). The performance effects of participative budgeting: An integration of intervening and moderating variables. Behavioral Research in accounting, 2(2), 104-123.

Negara, I. P. A. A., \& Budiartha, I. K. (2019). Effect of intervention of management and audit fee on auditor independence. International Research Journal of Management, IT and Social Sciences, 6(4), 31-36. https://doi.org/10.21744/irjmis.v6n4.639

Noviyanti, S. (2008). Skeptisme profesional auditor dalam mendeteksi kecurangan. Jurnal Akuntansi dan Keuangan Indonesia, 5(1), 102-125.

Octavian, N., \& Utami, I. (2016). Efek Halo dan Keputusan Audit: Studi Eksperimental Pengujian Bentuk dan Cara Penyajian Informasi.

O'Donnell, E., \& Schultz Jr, J. J. (2005). The halo effect in business risk audits: Can strategic risk assessment bias auditor judgment about accounting details?. The Accounting Review, 80(3), 921-939.

Peytcheva, M. (2014). Professional skepticism and auditor cognitive performance in a hypothesis-testing task. Managerial Auditing Journal.

Pramesthi, R. N., \& Cahyono, H. (2013). "Pengaruh pengangguran dan inflasi terhadap pertumbuhan ekonomi di kabupaten trenggalek. Ejurnal Unesa, 1(2).

Priesty, D. A. A. D., \& Budiartha, I. K. Pengaruh etika profesi dan komitmen profesional auditor terhadap kinerja auditor dengan skeptisisme profesional sebagai pemediasi. E-Jurnal Akuntansi, 1162-1188.

Purwanti, A., \& Prawironegoro, D. (2013). Akuntansi manajemen. Jakarta: Mitra Wacana Media.

Rahmawati, D., Marhaendraputro, E. A., Kurniawan, S. N., \& Wirathmawati, A. (2019). Extracranial metastasis of glioblastoma: a rare case. Malang Neurology Journal, 5(1), 51-54.

Rahmawati, I. (2007). Akram. 2007. Faktor-faktor yang Mempengaruhi Kebijakan Dividen dan Pengaruhnya Terhadap Nilai Perusahaan pada Perusahaan-perusahaan di BEJ Periode 2000-2004. Journal Riset Akuntansi Aksioma, 6, 3144.

Rusyanti, R. (2010). Pengaruh Sikap Skeptisme, Profesionalisme Auditor dan Tekanan Anggaran Waktu terhadap Kualitas Audit (studi empiris pada KAP di Jakarta Utara). Skripsi. fakultas Ekonomi dan Bisnis UIN Syarif Hidayatullah Jakarta.

Septian, I., \& Astika, I. B. P. (2019). Halo effect moderating: impact of professional skepticism on auditor performance. International Research Journal of Management, IT and Social Sciences, 6(4), 189-196.

https://doi.org/10.21744/irjmis.v6n4.680 
Santoso, B., Loukachev, I., Schoknecht, A., Schweitzer, M., Horn, M., Verma, S., ... \& Nagy, M. D. (2013). U.S. Patent No. 8,473,317. Washington, DC: U.S. Patent and Trademark Office.

Sari, G. D. P., Juliarto, A., \& Raharja, R. Evaluasi kinerja akuntan publik: skeptisme profesional dan outcome effect (sebuah studi eksperimental). jurnal akuntansi dan auditing, 14(2), 144-171.

Shefrin, H. (2016). Behavioral Risk Management: Managing the Psychology That Drives Decisions and Influences Operational Risk. Springer.

Thorndike, E. L. (1920). A constant error in psychological ratings. Journal of applied psychology, 4(1), 25-29.

Utama, M. S. (2016). Aplikasi Analisis Kuantitatif untuk Ekonomi dan Bisnis. Denpasar: CV. Sastra Utama.

Utami, I., Kusuma, I., Gudono, D., \& Supriyadi, D. (2014). Halo effect in analytical procedure: the impact of client profile and information scope. Global Journal of Business Research, 8(1), 9-26. 